\title{
A study in isolating circulating cancer cells from blood
}

\author{
B. V. NABAR \\ From the Department of Surgery, Bristol Royal Infirmary, Bristol
}

SYNOPSIS Samples of blood from 49 cancer cases were examined for free cancer cells. Cells identified as cancer cells were found in the blood of four. Cells which looked highly suspicious of beingo cancer cells were isolated from the blood of nine other cases. No conclusion was possible regardinger the type of cells in eight cases. This illustrates the difficulty of cytological diagnosis and shows the $e_{\omega}^{p}$ need for new methods of identification.

The problem of circulating free cancer cells in the blood of patients with cancer has been discussed by several investigators in recent years. This is due to the growing awareness of the importance of the biological aspects of cancer. Work on this problem was undertaken with the ultimate aim of utilizing the results in the control of the treatment of cancer with cytotoxic drugs.

The silicone flotation method described by Seal (1959) was used. This simple, inexpensive method makes use of the known differences in the specific gravity of the various cell types in blood.

Received for publication 7 November 1961.
MATERIAL

Samples of blood were collected from 52 unselected patients in whom the clinical diagnosis of malignantos tumour was considered. Three of these were later found ${ }^{N}$ to have benign conditions. In 47 cases the diagnosis was confirmed by histological examination of biopsy or operation specimens. In one case a radiological and in one other only a clinical diagnosis was made.

Peripheral blood samples were collected from armळ veins or from suitable arteries. Regional blood samples were obtained from the veins draining the tumour area.ō The blood was collected in bottles containing heparin and 3 processed without delay.

\section{TABLE}

ANALYSIS OF THE 'UNUSUAL' CELLS

Site of New Growth

No. of Cases

\begin{tabular}{ll}
$\begin{array}{l}\text { No. of Cases } \\
\text { with 'Unusual' } \\
\text { Cells }\end{array}$ & $\begin{array}{l}\text { 'Unusual' Cells } \\
\text { with Cancer } \\
\text { Cells }\end{array}$ \\
\hline
\end{tabular}

No. of Cases
with Suspi-
cious Cells

No. of Cases with Unidentifiable Cells

No. of Cases? Cells cious Cells with Unusual

Carcinoma stomach

Carcinoma breast

Carcinoma rectum

Melanoma Face 1 Upper alveolus 1 Leg 3

Basal cell carcinoma leg

Carcinoma colon

Carcinoma gall bladder

Carcinoma pancreas

Abdominal carcinomatoses (primary unknown)

Carcinoma oesophagus

Carcinoma ovary

Sarcoma breast

Carcinoma tongue

Seminoma testis

Carcinoma bronchus

Buccal squamous carcinoma

Fibrosarcoma thigh

Inguinal metastases from carcinoma of penis

5
11
6
5
1
2
2
3
4
2
1
1
1
1
1
1
1
1
49

\begin{tabular}{l}
4 \\
6 \\
2 \\
4 \\
1 \\
2 \\
2 \\
1 \\
2 \\
- \\
- \\
- \\
\hline 1 \\
1 \\
\hline 26
\end{tabular}




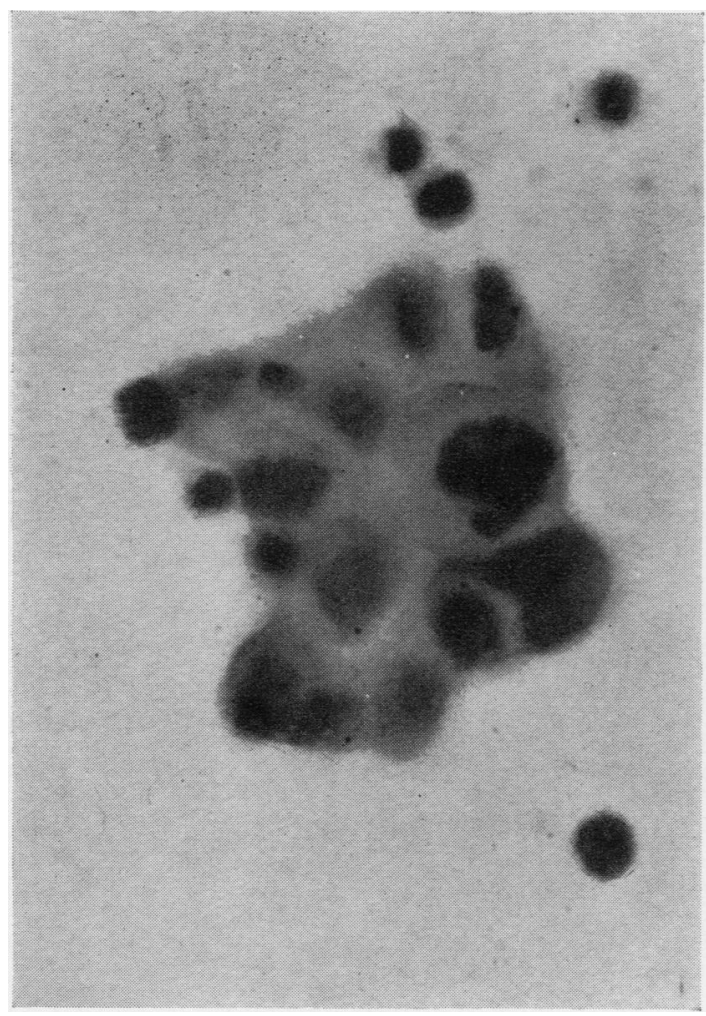

FIG. 1

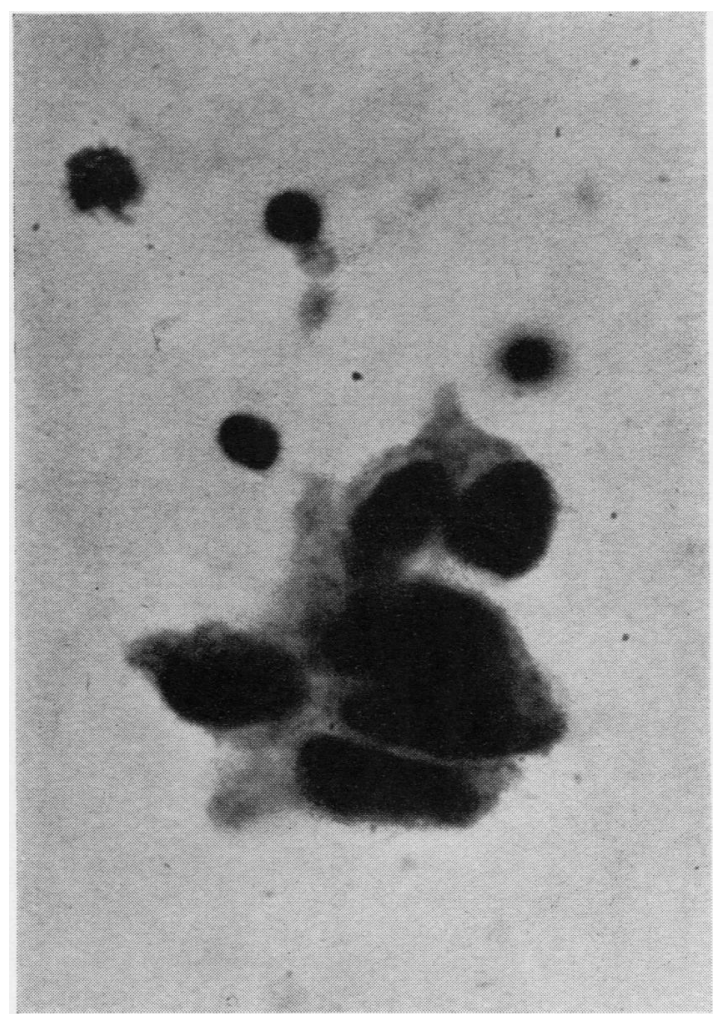

FIG. 2

FIG. 1. A group of cancer cells from the blood of a patient with scirrhous carcinoma of breast. One cell can be seen in prophase of mitosis $\times 1,300$. Haematoxylin and eosin.

FIG. 2. A group of tumour cells from the blood of a patient with carcinoma of stomach $\times 1,300$. Haematoxylin and eosin.

\section{ANALYSIS OF RESULTS}

Of the 49 cases, in 26 'unusual' cells were found in either peripheral or regional blood samples (Table). In eight of these, the actual type of cell could not be identified. In nine other cases, the cells looked highly suspicious of being cancer cells but their identity could not be certainly established. In only four cases was it certain that the isolated 'unusual' cells were cancer cells. These were cases of $(a)$ spheroidal cell scirrhous carcinoma of breast with no secondary deposits in the axillary lymph nodes (Fig. 1); (b) adenocarcinoma of stomach with lymph node metastases (Fig. 2); (c) poorly differentiated mucoid adenocarcinoma of gall bladder with metastases in the liver and all over the peritoneal cavity with ascites; and $(d)$ abdominal carcinomatosis from an unknown primary growth. In the remaining five of the 26 cases, the cells were identified as megakaryocytes or lymphoblasts or endothelial cells.
Of the 49 cancer cases, 21 could be grouped as curable and 28 as incurable (Long, Jonasson, Roberts, McGrath, McGrew, and Cole, 1960). In the former group, the disease was amenable to total ablative therapy, but not in the latter. Of the curable cases, two had cancer cells and two others highly suspicious ones. Of the 28 incurable cases, two had cancer cells and seven more highly suspicious ones.

In all, 132 blood samples were collected and examined. One hundred and twenty-six were from malignant tumour cases and six from benign cases. Of the 126 samples, 94 were peripheral and 32 regional. Cells which were identified as cancer cells were isolated from three peripheral samples. Cells which looked highly suspicious of being cancer cells were isolated from eight more peripheral samples. As regards the regional samples, one yielded cancer cells and two others highly suspicious ones. No unusual cells were isolated from the blood samples of the benign cases. 


\section{DISCUSSION}

No firm conclusions can be drawn from this small series. Nevertheless, it illustrates the notable difficulty of the problem of cytological demonstration of free cancer cells in blood. Definite identification of the tumour cells was possible in only four out of the 49, i.e., $8 \%$ of the malignant cases.

Alexander and Spriggs (1960) and Sandberg, Moore, and Schubarg (1959) have demonstrated a variety of benign cells of known and unknown origin occurring in the blood stream. Any of these may be confused with the free malignant cells. The 'false positive' blood samples mentioned by some authors indicate the uncertainty of cytological diagnosis based on morphological features (Long et al., 1960).
This uncertainty emphasizes the need for new methods of identification.

I am grateful to Prof. R. Milnes Walker for giving me the opportunity to work on this problem, and to Dr. $\mathrm{E}_{0}$ S. Meek for his invaluable help in cytological diagnosiso I wish to thank the surgeons of the various hospitals $i \frac{\bar{n}}{2}$ Bristol for their cooperation, and Mr. D. N. White of th Department of Pathology for the photomicrographs of the cells. The work was undertaken on a grant from the Medical Research Council.

\section{REFERENCES}

Alexander, R. F., and Spriges, A. I. (1960). J. clin. Path. 13, 414 Long, L., Jonasson, O., Roberts, S., McGrath, R., McGrew, E., an Cole, W. H. (1960). A.M.A. Arch. Surg., 80, 910.

Sandberg, A. A., Moore, G. E., and Schubarg, J. R. (1959). J. nat Cancer Inst., 22, 555.

Seal, S. H. (1959). Cancer, 12, 590 